\title{
Evaluation of diagnostic accuracy of portable echocardiography in newborns
}

\author{
Yenidoğanlarda taşınabilir ekokardiyografinin tanısal doğrululuğunun değerlendirilmesi
}

\author{
Aslınur Özkaya Parlakay, Tevfik Karagöz*, Süheyla Özkutlu*, Sema Özen*, Dursun Alehan*, Şule Yiğit**
}

From Departments of Pediatrics, *Pediatric Cardiology and **Neonatology, Faculty of Medicine, Hacettepe University, Ankara-Turkey

\section{ABSTRACT}

Objective: Congenital heart disease is the most common life-threatening anomaly in the neonatal period. Screening for this disease with portable echocardiography is crucial to diagnose in the early period, and it has benefits in saving time and decreasing the cost. Portable echocardiography has advantages of rapid access and lower costs and also has advantage that in intensive care units there is no necessity to move patients. With these advantages, it is aimed to compare the sensitivity of portable echocardiography comparing to standard echocardiography. Methods: In this study, the portable echocardiography results of the sequentially enrolled newborns hospitalized in the neonatal departments are revised. Portable echocardiography results were verified with standard echocardiography in $83(43 \%)$ female and 111 (57\%) male patients. This study was planned as a study on diagnostic accuracy.

Results: The gestational periods were between 24 weeks, 3 days and 42 weeks (average 35 weeks \pm 4 weeks 3 days). Birth weights were between 500 and 4850 grams (average $2370 \pm 936$ grams). The reason that portable echocardiography had been studied was murmur in $113(58.2 \%)$ patients, cyanosis in $47(24.2 \%)$ patients, prenatal anomaly in $12(6.2 \%)$ patients, bradycardia in $12(6.2 \%)$ patients, maternal diabetes in $6(3.1 \%)$ patients and respiratory distress in $4(2.1 \%)$ patients. Out of 194 patients $8(4.1 \%)$ had differences between standard and portable echocardiography. Compared to standard echocardiography, portable echocardiography has the sensitivity values ranged between $99.3-100 \%$ and the specificity values ranged between $90.9-100 \%$ in diagnosis of specific CHD anomalies. Positive predictive value was between $50-100 \%$ whereas negative predictive value was between $97.9-100 \%$. The agreement between results of two tests was determined as very good - kappa 0.886 , $95 \% \mathrm{Cl}-0.821-0.951, \mathrm{p}<0.0001$.

Conclusion: It is demonstrated that portable echocardiography has a high sensitivity especially diagnosing major heart defects, and with advantages of rapid access and lower costs it is estimated that increasing usage of portable echocardiography could be beneficial.

(Anadolu Kardiyol Derg 2011; 11: 627-32)

Key words: Congenital heart disease, standard echocardiography, portable echocardiography, sensitivity, specificity

ÖZET

Amaç: Yenidoğan döneminde konjenital kalp hastalıkları hayatı tehdit eden anomaliler içinde en sık olarak saptanmaktadır. Taşınabilir ekokardiyografi ile bu hastalıklara erken dönemde tanı konması büyük önem taşımakta, zaman ve maliyet açısından da büyük getirileri olmaktadır. Taşınabilir ekokardiyografinin daha hızlı ulaşılabilir, daha ekonomik olması ve özellikle yoğun bakım gibi hastaların yerinde tetkikinin gerektiği hastalarda uygulanmasının daha kolay olması nedeniyle taşınabilir ekokardiyografinin tanı koymadaki başarısının araştırıması planlanmıştır.

Yöntemler: Bu çalışmada, yenidoğan döneminde serviste yatırılarak izlenen hastaların ardışı olarak taşınabilir ekokardiyografi ile yapılan değerlendirme sonuçları özetlenmeye çalışılmıştır. Toplam 194 yenidoğan, 83 (\%43) kız, 111 (\%57) erkek hastada taşınabilir ekokardiyografi sonuçları standart ekokardiyografi ile konfirme edilmiştir. Bu çalışma tanısal doğruluğun değerlendirilmesi amacıyla planlanmıştır.

Bulgular: Çalışmaya dahil edilen hastaların doğum haftaları 24 hafta 3 gün ile 42 hafta arasında saptanmıştır (ortalama 35 hafta \pm 4 hafta 3 gün).

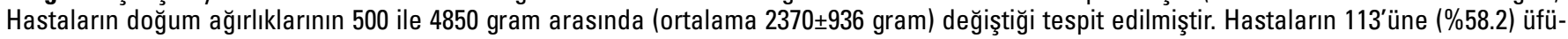
rüm, 47'sine (\%24.2) siyanoz, 12'sine (\%6.2) prenatal anomali, 12'sine (\%6.2) bradikardi, 6'sına (\%3.1) maternal diyabet ve 4'üne (\%2.1) solunum sıkıntısı nedeniyle ekokardiyografi yapılmıştır. Toplam 194 hastanın 8 'inin (\%4.1) tanısının standart ekokardiyografiden farklı olduğu saptanmıştır. Standart ekokardiyografi ile kıyaslandığında taşınabilir ekokardiyografinin duyarlılığı \%99.3-100 arasında özgüllüğü \%90.9-100 arasında olduğu

Address for Correspondence/Yazışma Adresi: Dr. Aslınur Özkaya Parlakay, Hacettepe Üniversitesi, Çocuk Sağlığı ve Hastalıkları Anabilim Dalı, 06100, Ankara-Turkey Phone: +90 3123051166 Fax: +90 3123108241 E-mail: aslinur@hacettepe.edu.tr

Accepted Date/Kabul Tarihi: 02.06.2011 Available Online Date/Çevrimiçi Yayın Tarihi: 29.09.2011

(C) Telif Hakkı 2011 AVES Yayıncılık Ltd. Şti. - Makale metnine www.anakarder.com web sayfasından ulaşılabilir.

(C) Copyright 2011 by AVES Yayıncilik Ltd. - Available on-line at www.anakarder.com doi:10.5152/akd.2011.167 
tespit edilmiştir. Taşınabilir ekokardiyografinin pozitif öngördürücü değerleri \%50-100 iken, negatif öngördürücü değerleri \%97.9-100\% olarak saptanmıştır. Iki test sonuçlarının arasında çok iyi uyumluluk değerleri tespit edildi - kappa 0.886, \%95GA -0.821-0.951, p<0.0001.

Sonuç: Taşınabilir ekokardiyografinin özellikle majör kalp defektlerinin saptamadaki hassasiyetinin yüksek olduğu, hızlı ulaşılabilir ve düşük maliyetli olduğu da göz önünde bulundurulduğunda klinikteki kullanımının yaygınlaştırılmasının avantajlarının olabileceği düşünülmüştür.

(Anadolu Kardiyol Derg 2011; 11: 627-32)

Anahtar kelimeler: Konjenital kalp hastalığı, standart ekokardiyografi, taşınabilir ekokardiyografi, duyarlııı, özgüllük

\section{Introduction}

Congenital heart disease (CHD) is the most common congenital anomaly in newborn. Incidence is around 5-8 in 1000 live births and it constitutes $10-25 \%$ of all congenital anomalies. CHD is observed $10-25 \%$ among abortus, $2 \%$ among premature newborns (1). Congenital heart defects have a wide spectrum of severity in infants: about 2-3 in 1000 newborn infants will be symptomatic with heart diseases in the 1st year of life. The diagnosis is established by 1 week of age in $40-50 \%$ of patients with congenital heart disease and 1 month of age in $50-60 \%$ of patients. With advances in both palliative and corrective surgery, the number of children with congenital heart disease surviving to adulthood has increased dramatically. Despite these advances, congenital heart disease remains the leading cause of death in children with congenital malformations. Congenital heart diseases might cause secondary defects in respiratory system, liver, kidneys and nervous system if not diagnosed and treated properly, because of that, early diagnosis is critically important (2).

Among noninvasive diagnostic tools, the most precious one is echocardiography. With the invention of ultrasound waves in 1877 , and the use of ultrasound waves in echocardiography in 1953, congenital heart diseases have been diagnosed in a much easier way. The development of color Doppler technology, echocardiography has become the corner stone of diagnosis in pediatric cardiology. Leatham et al. (3) have invented the first portable echocardiography in 1970s, so that this tool has become faster and cost effective.

There are studies to estimate sensitivity and specificity of portable echocardiography to increase usage of this fast and cost effective tool but more comprehensive studies are needed.

In a 300 patients case study from Netherlands, it is established that portable echocardiography decreased the need of studying standard echocardiography. In $78 \%$ of the patients, there was no need to repeat the study with standard echocardiography. This helped to consume time and decrease the cost. In the same study, it was stated that portable echocardiography is very sensitive in detecting major heart anomalies, it missed only $4 \%$ of the major heart defects and sensitivity is detected as $100 \%$, and the specificity as $96 \%$ (4).

In our study, the portable echocardiography results are compared with standard echocardiography, to find the sensitivity of portable echocardiography in newborns that were hospitalized between January 2002 and December 2008 in Hacettepe University, İhsan Doğramacı Children Hospital Neonatal Units.

\section{Methods}

\section{Study design and patients}

This study was planned on a basis of diagnostic accuracy. In 2002, cardiac evaluation of neonates was planned to be done by portable echocardiography (Siemens Acuson Cypress Card ${ }^{\circledR}$, Germany) in one hour after consultation. Patients diagnosed as having cardiac abnormalities were planned to underwent repeat standard echocardiographic study (GE Vingmed System $5^{\circledR}$, Horten, Norway) on the same day by the same cardiologist.

Between January 2002 and December 2008, 730 neonates were consecutively studied, $302(41.3 \%)$ of them were normal. Hospital records of 194 neonates that are hospitalized and studied with both portable and standard echocardiography during this period are investigated.

\section{Evaluation parameters of the study}

Name-surname, file number, gender, maternal age, diabetes history of the mother if present, birth weight, gestational age, fetal echocardiography if present, reason to study echocardiography, time period between portable echocardiography and control standard echocardiography, the treatment given (such as indomethacin and prostaglandin), diagnosis of portable echocardiography, diagnosis of standard echocardiography were noted. Reference parameter for the evaluation was standard echocardiography, whereas portable echocardiography was tested.

\section{Statistical analysis}

Statistical analysis, was studied with the help of "Statistical Package for Social Science (SPSS, IBM, New York, USA) 11.5 for Windows XP". Sensitivity (true positive/[true positive+false negative] ${ }^{*} 100$ ), specificity (true negative/[true negative+false positive] ${ }^{*} 100$ ), positive predictive (true positive/[true positive+ false positive] ${ }^{*} 100$ ) and negative predictive (true negative/ [true negative+false negative $]^{*} 100$ ) values were calculated via designated formulations. Inter-rater agreement was calculated with kappa test.

\section{Results}

Out of 194 patients $83(43 \%)$ were female and $111(57 \%)$ were male (Table 1). Gestational age of the newborns varied between 24.3 and 42 weeks (mean $34.7 \pm 4.3$ weeks). Birth weights were between 500 and $4850 \mathrm{~g}$ (mean $2370 \pm 936 \mathrm{~g}$ ). Patients weight 
Table 1. Demographic data of newborns

\begin{tabular}{|c|c|}
\hline Gestational age, weeks/days & \\
\hline Minimum & $24 w 3 d$ \\
\hline Maximum & $42 w$ \\
\hline Mean & $35 w$ \\
\hline St. Deviation & $4 w 3 d$ \\
\hline \multicolumn{2}{|l|}{ Birth weight, gr } \\
\hline Minimum & 500 \\
\hline Maximum & 4850 \\
\hline Mean & 2369.3 \\
\hline St. Deviation & 936.7 \\
\hline \multicolumn{2}{|l|}{ Gender, n } \\
\hline Female & 83 \\
\hline Male & 111 \\
\hline \multicolumn{2}{|l|}{ Mother age, years } \\
\hline Minimum & 16 \\
\hline Maximum & 43 \\
\hline Mean & 28.5 \\
\hline St. Deviation & 5.6 \\
\hline
\end{tabular}

distribution was as following: , one was $(0.5 \%)$ below 500 grams, $12(6.2 \%)$ were between $500-1000 \mathrm{~g}, 35(18 \%)$ were between $1000-1500 \mathrm{~g}, 49(25.3 \%)$ were between $1500-2500 \mathrm{~g}$, and $97(50 \%)$ were above $2500 \mathrm{~g}$. Maternal age ranged between 16 and 43 years (mean $28.5 \pm 5.6$ years).

The referral reasons for portable echocardiography evaluation were: murmur in $113(58.2 \%)$ newborn, cyanosis in $47(24.2 \%)$ patients, prenatal anomaly in $12(6.2 \%)$ newborn, bradycardia in $12(6.2 \%)$ newborn, gestational diabetes in $6(3.1 \%)$ cases, and respiratory difficulty in $4(2.1 \%)$ patients. Congenital heart defects of the patients were distributed as patent ductus arteriosus (PDA), most common as in $120(62.5 \%)$ patients, non-compaction in one $(0.4 \%)$ patient and atrioventricular septal defect (AVSD) in one $(0.4 \%)$ patient as the least common abnormality (Table 2).

The time difference between the portable echocardiography and control standard echocardiography ranged between 1-10 hours (mean 3.3 hours).

Compared to standard echocardiography, overall sensitivity of portable echocardiography in diagnosis of specific CHD was found to vary between $99.3-100$ and specificity90.9-100\% (Table 3). Positive and negative predictive values of portable echocardiography were-50-100\% and $97.9-100 \%$, respectively. There was a very good agreement (kappa $=0.886$, $95 \% \mathrm{Cl}-0.821-0.951, \mathrm{p}=<0.0001)$ between portable and standard echocardiography.

The diagnosis between standard echocardiography and portable echocardiography was different in 8 patients (Table 4). However, the only real misdiagnosis was missing of transposition of great arteries.
Table 2. Distribution of heart defects diagnosed with portable echocardiography

\begin{tabular}{|c|c|c|}
\hline Diagnosis & Patients, n & Patients, \% \\
\hline PDA & 120 & 62.5 \\
\hline ASD & 90 & 46.7 \\
\hline PHT & 44 & 22.9 \\
\hline PFO & 39 & 20.8 \\
\hline VSD & 35 & 17.9 \\
\hline TGA & 15 & 7.9 \\
\hline MR & 14 & 5.8 \\
\hline TR & 11 & 5.4 \\
\hline$A C$ & 10 & 5 \\
\hline PS & 9 & 4.6 \\
\hline HLHS & 8 & 4.2 \\
\hline AS & 6 & 3.3 \\
\hline PA & 5 & 2.9 \\
\hline $\mathrm{AR}$ & 4 & 1.7 \\
\hline Aortic interruption & 4 & 1.7 \\
\hline MS & 4 & 1.7 \\
\hline TAPVD & 4 & 1.7 \\
\hline PR & 3 & 1.3 \\
\hline $\mathrm{TA}$ & 3 & 1.3 \\
\hline DORV & 3 & 1.3 \\
\hline Situs inversus totalis & 2 & 0.8 \\
\hline Truncus arteriosus & 2 & 0.8 \\
\hline Ebstein's anomaly & 2 & 0.8 \\
\hline AVSD & 1 & 0.4 \\
\hline $\begin{array}{l}\text { Isolated left ventricular } \\
\text { non-compaction }\end{array}$ & 1 & 0.4 \\
\hline \multicolumn{3}{|c|}{$\begin{array}{l}\text { AC - coarctation of aorta, AR - aortic regurgitation, AS - aortic stenosis, ASD - atrioseptal } \\
\text { defect, AVSD - atrioventricular septal defect, DORV - double outlet right ventricle, } \\
\text { HLHS - hypoplastic left heart syndrome, MR - mitral regurgitation, MS - mitral stenosis, } \\
\text { PA - pulmonary atresia, PDA - patent ductus arteriosus, PFO - patent foramen ovale, } \\
\text { PHT - pulmonary hypertension, PR-pulmonary regurgitation, PS - pulmonary stenosis, } \\
\text { TA - tricuspid atresia, TAPVD - total abnormal venous defect, TGA - transposition of great } \\
\text { arteries, TR - tricuspid regurgitation, VSD - ventriculoseptal defect }\end{array}$} \\
\hline
\end{tabular}

\section{Discussion}

According to our study, portable echocardiography has a high sensitivity and positive predictive value in diagnosis of $\mathrm{CHD}$. There was a very good agreement (kappa $=0.886, p<0.0001$ ) between portable and standard echocardiography results.

Congenital heart disease is the most common life threatening congenital anomaly. Deaths due to congenital heart diseases constitute half of the deaths caused by congenital anomalies. It is crucial to diagnose these defects early. As the echocardiography machine became smaller and easily transportable in 1970, this tool found higher chance in cardiology practice as it was faster and easily applicable. As the pediatric population had thinner chest wall and less rib shadowing very successful find- 
Table 3. Sensitivity and specificity of portable echocardiography according to heart defects

\begin{tabular}{|c|c|c|c|c|c|c|c|}
\hline & Sensitivity, \% & Specificity, \% & PPV, \% & NPV, \% & Kappa & $\mathbf{p}$ & $95 \% \mathrm{CI}$ \\
\hline PDA & 100 & 96 & 88.2 & 100 & 0.838 & $<0.0001$ & $0.76-0.915$ \\
\hline PHT & 99.3 & 93.6 & 93.6 & 99.3 & 0.943 & $<0.0001$ & $0.888-0.998$ \\
\hline ASD & 100 & 94.5 & 94.5 & 100 & 0.948 & $<0.0001$ & $0.903-0.993$ \\
\hline VSD & 99.4 & 100 & 100 & 99.4 & 0.977 & $<0.0001$ & $0.933-1$ \\
\hline MS & 100 & 100 & 100 & 100 & 0.664 & $<0.0001$ & $0.681-1$ \\
\hline MR & 99.5 & 90.9 & 81.8 & 99.5 & 0.849 & $<0.0001$ & $0.665-1$ \\
\hline $\mathrm{TA}$ & 100 & 100 & 50 & 100 & 0.664 & $<0.0001$ & $0.416-1$ \\
\hline TR & 99.5 & 100 & 100 & 99.5 & 0.957 & $<0.0001$ & $0.41-1$ \\
\hline AS & 99.5 & 100 & 100 & 99.5 & 0.886 & $<0.0001$ & $0.371-0.936$ \\
\hline$A R$ & - & - & - & - & - & - & - \\
\hline PA & 100 & 100 & 66.7 & 100 & 0.797 & $<0.0001$ & $0.41-1$ \\
\hline PS & 100 & 100 & 83.3 & 97.9 & 0.654 & $<0.0001$ & $0.371-0.936$ \\
\hline PR & 100 & 100 & 100 & 100 & 1 & $<0.0001$ & 1 \\
\hline PFO & 99.3 & 96 & 87 & 99.3 & 0.896 & $<0.0001$ & $0.821-0.971$ \\
\hline HLHS & 100 & 100 & 83.3 & 100 & 0.906 & $<0.0001$ & $0.724-1$ \\
\hline $\mathrm{AC}$ & 100 & 100 & 75 & 100 & 0.855 & $<0.0001$ & $0.573-1$ \\
\hline DORV & 100 & 100 & 100 & 100 & 1 & $<0.0001$ & 1 \\
\hline TGA & 100 & 100 & 75 & 100 & 0.855 & $<0.0001$ & $0.573-1$ \\
\hline TAPVD & 100 & 100 & 100 & 100 & 1 & $<0.0001$ & 1 \\
\hline AVSD & 100 & 100 & 100 & 100 & 1 & $<0.0001$ & 1 \\
\hline Ebstein's anomaly & 100 & 100 & 100 & 100 & 1 & $<0.0001$ & 1 \\
\hline Situs inversus totalis & 100 & 100 & 100 & 100 & 1 & $<0.0001$ & 1 \\
\hline \multicolumn{5}{|c|}{ Total portable echocardiography } & 0.886 & $<0.0001$ & $0.821-0.951$ \\
\hline \multicolumn{8}{|c|}{$\begin{array}{l}\text { AC - coarctation of aorta, AR - aortic regurgitation, AS - aortic stenosis, ASD- atrioseptal defect, AVSD - atrioventricular septal defect, DORV - double outlet right ventricle, } \\
\text { HLHS - hypoplastic left heart syndrome, MR - mitral regurgitation, MS - mitral stenosis, NPV - negative predictive value, PA - pulmonary atresia, PDA - patent ductus arteriosus, } \\
\text { PFO - patent foramen ovale, PHT - pulmonary hypertension, PPV - positive predictive value, PR - pulmonary regurgitation, PS - pulmonary stenosis, TA - tricuspid atresia, TAPVD - total } \\
\text { abnormal venous defect, TGA - transposition of great arteries, TR - tricuspid regurgitation, VSD - ventriculoseptal defect }\end{array}$} \\
\hline
\end{tabular}

Table 4. The patients misdiagnosed with portable echocardiography

\begin{tabular}{|l|c|}
\hline $\begin{array}{l}\text { Portable } \\
\text { echocardiography }\end{array}$ & $\begin{array}{c}\text { Standard } \\
\text { echocardiography }\end{array}$ \\
\hline PDA+MR & PDA \\
\hline PDA+ASD & PDA \\
\hline PDA+PFO+AR+MR & PDA+PFO \\
\hline TA+PA+MY+PFO & TA+PA+PFO \\
\hline TAPVD & TAPVD+AR \\
\hline AR & AR+MR \\
\hline MR+TR+AR+PR & MR+TR+AR \\
\hline TA+PS+ASD+VSD+PDA & TA+PS+ASD+VSD+PDA+TGA \\
\hline $\begin{array}{l}\text { AR - aortic regurgitation, } \text { ASD - atrioseptal defect, MR - mitral regurgitation, PA - pulmo- } \\
\text { nary atresia, PDA - patent ductus arteriosus, PFO - patent foramen ovale, PR - pulmo- } \\
\text { nary regurgitation, PS - pulmonary stenosis, TA - tricuspid atresia, TGA - transposition } \\
\text { of great arteries, TR - tricuspid regurgitation, VSD - ventriculoseptal defect }\end{array}$ \\
\hline
\end{tabular}

ings are observed with portable echocardiography (5). In a study from Washington, portable echocardiography compared to standard echocardiography, was found more cost effective and time sparing (6). Portable echocardiography has advantages of rapid access and lower costs and also has advantage that there is no necessity to move patients which is important in intensive care units. In our study sensitivity of portable echocardiography is calculated as high as the literature data, but specificity is lower than previous studies.

In some studies, it is stated that congenital heart diseases are found more common in premature newborns. In a study from England, among 521.619 newborns in a time period of 14 years frequency is determined as 5.7 out of 1000 newborns while it increased to 12.5 out of 1000 in premature babies. It is also stated that patients having congenital heart diseases were premature in a percentage of $16 \%$ (atrioseptal defect and patent ductus arteriosus is excluded in this study) (7). In our study, patients having congenital heart disease are premature in a percentage of $72.9 \%$. This high ratio of premature patients might 
be not only because atrioseptal defect and patent ductus arteriosus is excluded but our center is a well known unit for following premature patients and from that reason high risk patients could have been referred to our center. Due to some data cardiac conditions which can be resolved with therapy such as PDA are more common in premature infants but congenital heart disease are not.

Rivera et al. (8) has detected the reasons to study echocardiography as: $72 \%$ murmur, $14 \%$ cyanosis, $10 \%$ respiratory failure. Kadivar et al. (9) declared the most common echocardiography reasons as murmur with a $45 \%$ percentage and prenatal anomaly with $\% 24$ percentage.

In our study reasons for echocardiography study were $58.7 \%$ murmur, $22.9 \%$ cyanosis, $7.1 \%$ prenatal anomaly, $6.3 \%$ bradycardia, $2.5 \%$ gestational diabetes, $2.5 \%$ respiratory failure. The reason that prenatal anomaly does not constitute a high percentage in our study might be lack of having enough prenatal follow-ups especially with fetal echocardiography.

In a study from Nigeria, distribution of congenital heart diseases are; $41.7 \%$ ventricular septal defect (VSD), $20.2 \%$ atrioseptal defect (ASD), 7\% AVSD, 5.7\% PDA, 3.1\% pulmonary stenosis (PS), 2.2\% transposition of the great arteries (TGA) and single ventricle (10).

In a different study from Bosnia, it is stated that congenital heart disease frequency is 6.12 out of 1000 births and the distribution is as follows; $40.7 \%$ VSD, 10.7\% ASD, 8.6\% AVSD, 7.8\% PDA, 7.4\% PS, 5.4\% tetralogy of Fallot (TOF), 4.5\% TGA, 3.3\% aortic stenosis (AS), $2.9 \%$ coarctation of aorta (AC), 2.9\% tricuspid atresia (TA), 1.7\% double outlet right ventricular (DORV), $1.7 \%$ hypoplastic left heart syndrome, $\% 0.8$ total abnormal pulmonary venous defect (TAPVD), $0.4 \%$ Ebstein anomaly and $0.8 \%$ as others (11).

In an another study, congenital heart diseases have the following distribution $38.8 \%$ VSD, 22.5\% ASD, 10.2\% AVSD, 6.2\% PS, $6.2 \%$ with TOF, 4.1\% DORV, $2 \%$ aortic interruption, $2 \%$ TGA, $2 \%$ truncus arteriosus, $2 \%$ pulmonary atresia. In this study distribution is stated as heart diseases other than PDA. The cases were found normal in $50 \%$ of patients, $36 \%$ as having PDA, $14 \%$ are the cases having the above distribution (12).

The distribution of congenital heart diseases in our study were $62.5 \%$ PDA, $46.7 \%$ ASD, $22.9 \%$ pulmonary hypertension, $20.8 \%$ PFO, $17.9 \%$ VSD, $7.9 \%$ TGA, 5.8\% mitral regurgitation, $5.4 \%$ tricuspid regurgitation, 5\% AC, $4.6 \%$ PS, 4.2\% hypoplastic left heart syndrome, 3.3\% AS, 2.9\% PA, 2.1\% aortic regurgitation, 2.1 $\%$ aortic interruption, $1.7 \% \mathrm{MS}, 1.7 \%$ TAPVD, $1.3 \%$ pulmonary regurgitation, $1.3 \% \mathrm{TA}, 1.3 \% \mathrm{DORV}, 0.8 \%$ situs inversus, $0.8 \%$ truncus arteriosus, $0.8 \%$ Ebstein anomaly, $0.4 \%$ noncompaction, $0.4 \%$ AVSD. As some congenital heart diseases accompany the others, distribution, is presented according to presence of each type of congenital heart disease. Because of this reason, summation of the percentages is above $100 \%$.
Fedson et al. (13) detected that in $17 \%$ of the patients having normal physical examination, had serious heart findings with portable echocardiography.

Gorcsan et al. (14) found that portable echocardiography detected such important findings that changed the treatment plan in $60 \%$ of the patients. In our study, treatment plans were changed in $104(53.6 \%)$ patients.

In a 300 patients case study from Holland, it is established that portable echocardiography decreased the need of studying standard echocardiography. In $78 \%$ of the patients, there was no need to repeat the study with standard echocardiography. This helped to consume time and decrease the cost. In the same study, it is stated that portable echocardiography is very sensitive in detecting major heart anomalies, it missed only $4 \%$ of the major heart defects and sensitivity is detected as $100 \%$, and the specificity as $96 \%$ (4). Spencer et al. (15), and also Galasko et al. (16) detected that portable echocardiography could miss minor heart defects such as minor regurgitation. Patients having major heart defects have been diagnosed correctly with a percentage of $98.9 \%$.

In the first studies with portable echocardiography, sensitivity was $85 \%$ whereas specificity was $90 \%$ (14), but with the technological development and the increase in experience with portable echocardiography sensitivity increased to $96.6 \%$ and specificity increased to $99.3 \%$ (17).

\section{Study limitations}

Limitations of our study were having only few patients for some rare disorders so that calculation of sensitivity and specificity, positive and negative predictive values might not be accurate for these specific disorders.

\section{Conclusion}

In our study major part of the patients, especially the ones having major heart defects were diagnosed correctly with the help of portable echocardiography. There was a very good agreement (kappa $=0.886,0.821-0.951, \mathrm{p}<0.0001$ ) between portable and standard echocardiography. By having the true diagnosis, treatment plans could be adjusted appropriately and lifesaving procedures could be initiated immediately.

\section{Acknowledgement}

Project was funded by Hacettepe University (Project no: 02G117).

Conflict of interest: None declared.

\section{References}

1. Ferencz C, Rubin JD, McCarter RJ, Brenner JI, Neill CA, Perry LW, et al. Congenital heart disease: Prevalence at live-birth. The Baltimore-Washington Infant study. Am J Epidemiol 1985; 121: 31-6.

2. Bernstein D. Congenital Heart disease. In: Behrman R, Kliegman $R$, Jenson $\mathrm{H}$ (editors). Nelson Textbook of Pediatrics (17th edition). Philadelphia: Saunders;2004.1499-544. 
3. Leatham A. Auscultation of the heart and phonocardiography, 1st ed. London, J\&A Churchill, 1970: 25-57.

4. Bruce CJ, Prince DJ, Zummach PL, Montgomery SC, Seward JB. Handheld ultrasound imager: Utility in the cardiology in-patient setting. (Abstract P3-41). J Am Soc Echocardiogr 2001; 14: 470.

5. Sani M. Spectrum of congenital heart disease in a tropical environment: an echocardiography study. J Natl Med Assoc 2007; 99: 665-9.

6. Spurney C, Sable C, Berger J, Martin G. Use of a hand-carried ultrasound device by critical care physicians for the diagnosis of pericardial effusions, decreased cardiac function, and left ventricular enlargement in pediatric patients. J Am Soc Echocardiogr 2005; 18: 313-9.

7. Tanner K, Sabrine N. Cardiovascular malformations among preterm infants. Pediatrics 2005; 116: 833-8.

8. Rivera I, Silva M, Fernandes JM, Thomaz AC, Soriano CF, Souza MG. Congenital heart diseases in the newborn: from the pediatrician's request to the cardiologist's evaluation. Arq Bras Cardiol 2007; 89: 6-10. [CrossRef]

9. Kadivar M, Kiani A, Kocharian A, Shabanian R, Nasehi L, Ghajarzadeh M. Echocardiography and management of sick neonates in the intensive care unit. Congenit Heart Dis. 2008; 3: 325-9. [CrossRef]

10. Okoromah C, Ekure E, Ojo 00, Animasahun BA, Bastos MI. Structural heart disease in children in Lagos: profile, problems and prospects. Niger Postgrad Med J 2008; 15: 82-8.
11. Begic $\mathrm{H}$, Tahirovic $\mathrm{H}$, Mesihovic-Dinarevic S, Ferkovic V, Atic N, Latifagic A. Epidemiological and clinical aspects of congenital heart disease in children in Tuzla Canton, Bosnia-Herzegovina. Eur J Pediatr 2003; 162: 191-3.

12. Dickinson D, Arnold R, Wilkinson JL. Congenital Heart disease among 160.480 liveborn children in Liverpool 1960 to 1969. Implications for surgical treatment. Br Heart J 1981;46: 55-62.

13. Fedson S, Neithardt G, Thomas P, Lickerman A, Radzienda M, DeCara JM, et al. Unsuspected clinically important findings detected with a small portable ultrasound device in patients admitted to a general medicine service. J Am Soc Echocardiogr 2003; 16: 901-5. [CrossRef]

14. Gorcsan J 3rd, Pandey P, Sade LE. Influence of hand-carried ultrasound on bedside patient treatment decisions for consultative cardiology. J Am Soc Echocardiogr 2004; 17: 50-5. [CrossRef]

15. Spencer K, Anderson A, Bhargava A, Bales AC, Sorrentino M, Furlong $K$, et al. Physician-performed point-of-care echocardiography using a laptop platform compared with physical examination in the cardiovascular patient. J Am Coll Cardiol 2001; 37: 2013-8. [CrossRef]

16. Galasko G, Lahiri A, Senior R. Portable echocardiography: an innovative tool in screening for cardiac abnormalities in the community. Eur J Echocardiogr 2003; 4: 119-27. [CrossRef]

17. Rugolotto M, Hu B, Liang D, Schnittger I. Rapid assessment of cardiac anatomy and function with a new hand-carried ultrasound device (OptiGo): a comparison with standard echocardiography. Eur J Echocardiogr 2001; 2: 262-9. 